\title{
Description and ecology of a new species of sun spider (Arachnida: Solifugae) from the Brazilian Cerrado
}

\author{
EDUARDO G. MARTINS $\uparrow$, VINÍCIUS BONATO†t, \\ GLAUCO MACHADO* $\S$, RICARDO PINTO-DA-ROCHA and \\ LINCOLN S. ROCHA ††
}

$\uparrow$ Programa de Pós-graduação em Ecologia, Instituto de Biologia, Universidade Estadual de Campinas, CP 6109, 13083-970 Campinas $S P$, Brazil

$\ddagger$ Instituto de Ciências Biológicas, Centro Regional Universitário Espírito Santo do Pinhal, Av. Hélio Vergueiro Leite, s/n, 13990-000, Espírito Santo do Pinhal SP, Brazil

$\S$ Museu de História Natural, Instituto de Biologia, Universidade Estadual de Campinas, CP 6109, 13083-970 Campinas SP, Brazil; e-mail: glaucom@unicamp.br

-Departamento de Zoologia, Instituto de Biociências, Universidade de São Paulo, Rua do Matão, Travessa 14, No.321, 05508-900 São Paulo SP, Brazil; e-mail: ricrocha@usp.br

$\dagger+$ Departamento de Biologia, Instituto de Biociências, Universidade de São Paulo, Rua do Matão, 277, 05508-900 São Paulo SP, Brazil; e-mail: linrocha@ib.usp.br

\section{(Accepted 23 September 2003)}

A new species of solifuge from São Paulo State, south-eastern Brazil, is described, together with its phenology, habitat use, activity pattern and the effect of fire on the population. Muтmucia coaraciandu n. sp. differs from other Mummuciidae in cheliceral dentition and pleurite coloration. Over a one-year period, 649 individuals of $M$. coaraciandu were captured in 72 pitfall traps distributed in three Cerrado physiognomies: borders of gallery forest $(N=53)$, campo sujo $(N=561)$ and campo cerrado $(N=35)$. The species is diurnal and showed two peaks of surface activity during the year: the highest peak occurred in the cold-dry season (June to July) and the smaller peak in the middle of the warm-wet season (December to February). The number of individuals per trap was negatively correlated with the mean monthly temperature, but showed no correlation with the monthly precipitation. The sex ratio was male-biased $(7: 1)$ and the number of males trapped was positively correlated with the number of reproductive females. More individuals were trapped in burned areas when compared with unburned areas 1 month after the fire. This difference between the two areas was not observed 1 month before and 3-4 months after the passage of the fire (when the vegetation had recovered). Muтmucia coaraciandu

*To whom correspondence is addressed. 
is the second solifuge described from the Brazilian Cerrado and its ecology is very similar to that of Muтmисia mauryi from Caatinga vegetation.

KeYwords: Activity pattern, campo cerrado, campo sujo, fire, gallery forest, habitat use, phenology, population ecology, taxonomy.

\section{Introduction}

Solifuges are a small group of arachnids ( $c a 1000$ species) found mainly in arid and semi-arid regions worldwide (Cloudsley-Thompson, 1977). There are 70 nominal species described from the neotropics (Rocha and Cancello, 2002a), although only a few dozen specimens are deposited in South American museums. As a consequence, only three species have been described from Brazil in the last century (Mello-Leitão, 1924; Roewer, 1934, 1954): Gaucha fasciata Mello-Leitão, 1924 (State of Rio Grande do Sul, southern Brazil), Metacleobis fulvipes Roewer, 1934 from Cuiabá (State of Mato Grosso, central Brazil) and Ammotrecha friedlaenderi Roewer, 1954 (State of Rio de Janeiro, south-eastern Brazil). Recently, a new species, Mummucia mauryi, occurring in north-eastern Brazil, was described (Xavier and Rocha, 2001), and a second species, M. fulvipes, was redescribed (Rocha and Cancello, 2002b).

Most studies on the ecology of the solifuges have been done with North American and African species (see Punzo, 1998). Knowledge of the order in the Neotropical region is scarce, especially in Brazil. Although xeric landscapes, such as the Caatinga and the Cerrado, occupy a large area of Brazil, few solifuge species are known to occur in these biomes. The only species studied so far is M. mauryi Rocha, 2001 from sand dunes in the semi-arid Caatinga (Xavier and Rocha, 2001). Contrary to the large solifuges that are nocturnal and spend the daytime in their burrows (CloudsleyThompson, 1977), this small species is diurnal (Xavier and Rocha, 2001).

In this report, we describe a new species of solifuge from the Itirapina Ecological Station, a Cerrado fragment in south-eastern Brazil, as well as some aspects of its ecology, including phenology, habitat use and activity pattern. Since Cerrado vegetation burns frequently, either by lightning-initiated or by human-provoked fires (Miranda et al., 2002), and since during this work part of the study area was burned, we also examined the effect of fire on the population of this species.

\section{Study site}

Fieldwork was done at the Itirapina Ecological Station (IES), located in the municipality of Itirapina $\left(22^{\circ} 15^{\prime} \mathrm{S} ; 47^{\circ} 49^{\prime} \mathrm{W}\right)$, São Paulo State, south-eastern Brazil (figure 1A). The study site covers an area of $c a 65.8 \mathrm{~km}^{2}$, of which $c a 23.0 \mathrm{~km}^{2}$ corresponds to natural Cerrado (savanna-like) vegetation. Three different physiognomies occupy most of the area: campo sujo, campo cerrado and gallery forest (figure 1B). Campo sujo is a field composed predominantly of herbaceous vegetation and sparsely scattered shrubs, small trees (2-3 m high) and acaulescent palms. Campo cerrado is a half-closed field with woody vegetation, the trees being small but taller and denser than in campo sujo. Gallery forest consists of trees (10-20 m high) with a low, dense understorey vegetation (see Oliveira-Filho and Ratter, 2002). The occurrence of gallery forests at the IES is restricted to narrow strips along the sides of small rivers and streams. 

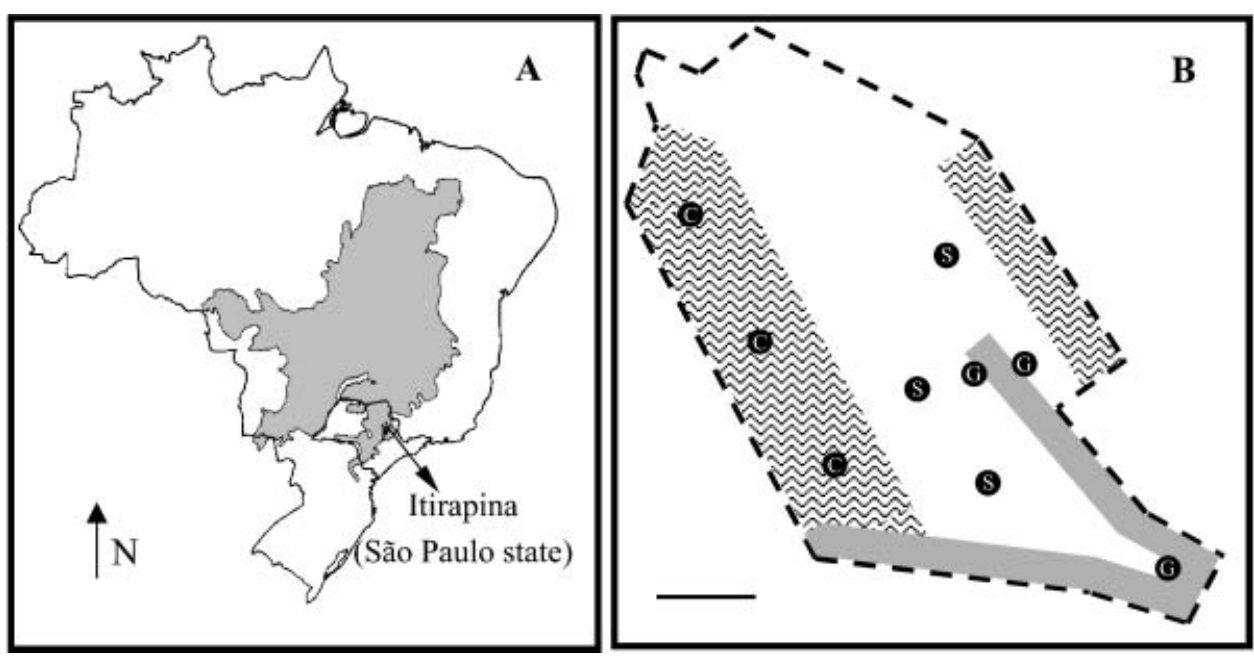

Fig. 1. (A) Area of Brazil occupied by Cerrado vegetation and location of Itirapina city, São Paulo State, south-eastern Brazil; (B) map of the Itirapina Ecological Station showing the three Cerrado physiognomies and the location of the lines containing eight traps (black dots). S, Campo sujo (white); C, campo cerrado (hatched); G, gallery forest (grey). Scale bar: $1 \mathrm{~km}$.

The climate of the region is mesotermic, with two well-defined seasons: a warmwet season, between October and March, and a cold-dry season, between April and September (figure 5A). During the period of this study, the monthly rainfall and the mean monthly temperature ranged, respectively, from 124.7 to $423 \mathrm{~mm}$ and 23.7 to $25.4^{\circ} \mathrm{C}$ in the warm-wet season, and from 5 to $122 \mathrm{~mm}$ and 16.4 to $22.1^{\circ} \mathrm{C}$ in the cold-dry season.

\section{Materials and methods}

\section{Taxonomy}

The cheliceral dentition formulae, leg spination formulae and chetotaxy terminology were based on Xavier and Rocha (2001) and Rocha and Cancello (2002b). Type material was deposited in the Museu de Zoologia da Universidade de São Paulo (MZSP), Museu Nacional do Rio de Janeiro (MNRJ) and Instituto Butantan (IBSP).

\section{Ecological methodology}

The phenology, habitat use and activity pattern of the species were investigated from May 2000 to April 2001. Individuals were captured in 72 pitfall traps with drift fences to increase the capture rate (see Punzo, 1998). A comparative study of the different methods for capturing solifuges demonstrated that pitfall traps are the most efficient and reliable for estimating the population size and its seasonal variations (Muma, 1980). Eighteen $45 \mathrm{~m}$-long lines containing four pitfall traps each (100-litre plastic pails; $65 \mathrm{~cm}$ high $\times 50 \mathrm{~cm}$ in diameter; $15 \mathrm{~m}$ apart) were set up at the study site. There were six lines $(100-500 \mathrm{~m}$ apart) in each type of vegetation (campo sujo, campo cerrado and borders of gallery forest) (figure 1B). The drift fences were made of plastic mesh fixed with sticks, and were $50 \mathrm{~cm}$ high, with an 
additional $10 \mathrm{~cm}$ buried in the soil. Each trap had a plate of Styrofoam $(20 \times 20 \mathrm{~cm})$ to provide shade and a small vial with water to prevent dehydration of the arthropods. Pitfalls were not filled with preservation liquid in order to avoid killing non-target species, such as vertebrates (see New, 1999), and also because the traps were inspected at short intervals (12 or $24 \mathrm{~h}$, see below). This regular inspection minimized the predation within the traps. Solifuges were unable to climb the smooth vertical surface of the pail.

The traps were set twice a month over a $24 \mathrm{~h}$ period and all arthropods captured were collected and preserved in $70 \%$ ethanol. Each $24 \mathrm{~h}$ period was considered a sampling occasion. On three sampling occasions (one each in July, September and November), the traps were flooded by rainwater and the arthropods collected were not included in the analyses. On three further sampling occasions during the colddry season (June, July and August) and on three occasions in the warm-wet season (November, December and January), the pitfalls were checked at $12 \mathrm{~h}$ intervals to determine the activity pattern (diurnal versus nocturnal) of the solifuges. The individuals captured in these two intervals were later pooled to complete a sampling occasion for the other ecological analyses.

\section{Laboratory procedures}

The sex and developmental stage of all trapped individuals were determined in the laboratory. Females were dissected to assess their reproductive condition. Ovaries were classified based on their external appearance as: (a) partially developed, in which the ovary length reached the middle of the female's abdomen and contained many small $(<0.5 \mathrm{~mm})$, generally white-coloured eggs, or (b) fully developed, in which the ovary length reached more than two-thirds of the female's abdomen and contained many large $(>0.5 \mathrm{~mm})$, generally yellow-coloured eggs. Females were classified as non-reproductive when the ovary was greatly reduced and did not fit the two categories above.

\section{Data analysis}

Regression analysis was used to evaluate the relationship between the number of solifuges trapped per month and the mean monthly rainfall and mean monthly temperature (Sokal and Rohlf, 1995). To correct for different sampling efforts between months, these analyses were done by considering the number of individuals captured per trap. A Chi-square test using all individuals collected in each vegetation type was used to assess whether the individuals were distributed randomly among the three Cerrado physiognomies (Sokal and Rohlf, 1995). A Spearman rank correlation was used to test the relationship between the number of males trapped per month and the number of reproductive females (considered here as those with partially and fully developed ovaries).

The area around three $45 \mathrm{~m}$-long lines in campo sujo accidentally burned at the end of July 2000. The effect of the fire on the solifuge population was evaluated by comparing (Chi-square test) the total number of individuals collected along the three burned lines with the number collected in the three adjacent unburned lines of campo sujo. The comparison was done for three periods: 1 month before the fire (July), 1 month after the fire (August) and 3-4 months after the fire (October to November), when the vegetation of the area had apparently recovered. 

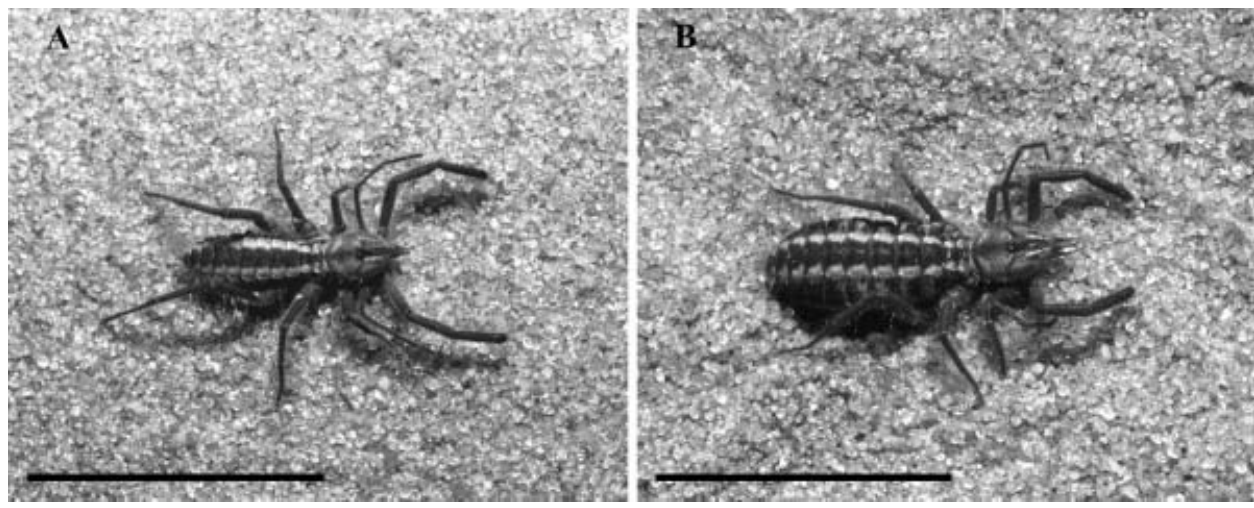

Fig. 2. Mummucia coaraciandu n. sp., live. (A) Male; (B) female. Scale bar: $1 \mathrm{~cm}$. Photograph: R. J. Sawaya.

\section{Results}

\section{Family MUMMUCIIDAE}

Mummucia coaraciandu Pinto-da-Rocha and Rocha, n. sp. (figures 2-4)

Types

Holotype: male, MZSP-20948, Brazil, São Paulo, Itirapina, 2-4 September 1999, G. Machado leg.

PARATYPES: same data as holotype, male (MZSP-20409); female (MZSP-20500); one male and one female (MNRJ and IBSP).
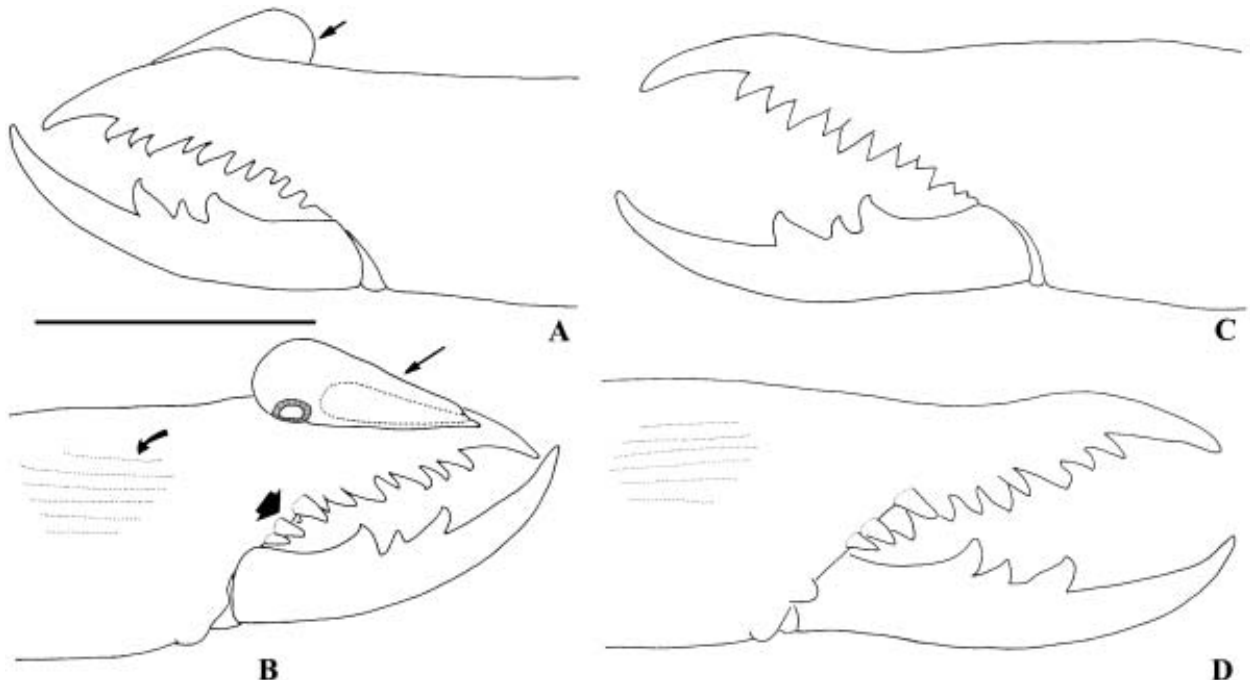

FIg. 3. Mummucia coaraciandu n. sp., left chelicera. (A, B) Male (holotype). (A) Ectal view. Arrow indicates the flagellum. (B) Mesal view. Long arrow indicates the flagellum, with the ectal longitudinal opening depicted in dotted line; curved arrow indicates grooves belonging to the stridulatory apparatus; short arrow indicates the three mesal fondal teeth. (C, D) Female (paratype). (C) Ectal view. (D) Mesal view. Scale bar: $1 \mathrm{~mm}$. 


\section{Etymology}

From Tupi, an ancient Indian language, coaraci $=$ sun and $i a n d u=$ spider. This name was based on the common English name of 'sun-spider' for the Solifugae. This name, however, is not used by Brazilian Indians.

\section{Diagnosis}

Mummucia coaraciandu n. sp. is the only species of Mummuciidae with cheliceral dentition and pleurite coloration as depicted in figures 3 and $4 \mathrm{E}, \mathrm{F}$, respectively. In the cheliceral fixed finger of both males and females, the three anterior teeth are placed in a slightly prominent projection so that they are not completely aligned with the other teeth.

\section{Description of male (figures $2 \mathrm{~A}, 3 \mathrm{~A}, \mathrm{~B}, 4 \mathrm{~B}-\mathrm{E}$ )}

Coloration in $70 \%$ ethanol. Prosoma: propeltidium white, with central portion brown and narrower than the ocular tubercle, dark brown near the lateral lobe grooves. Ocular tubercle with a longitudinal white narrow stripe between the eyes and a black ring surrounding each eye. Peltidium white and parapeltidium yellowish. Mesopeltidium and metapeltidium with a brown central stripe and lateral white stripes, each stripe a third of the tergite width. Chelicerae pale brown, with four longitudinal, distally fused, white stripes on the ectal face. Pedipalpi
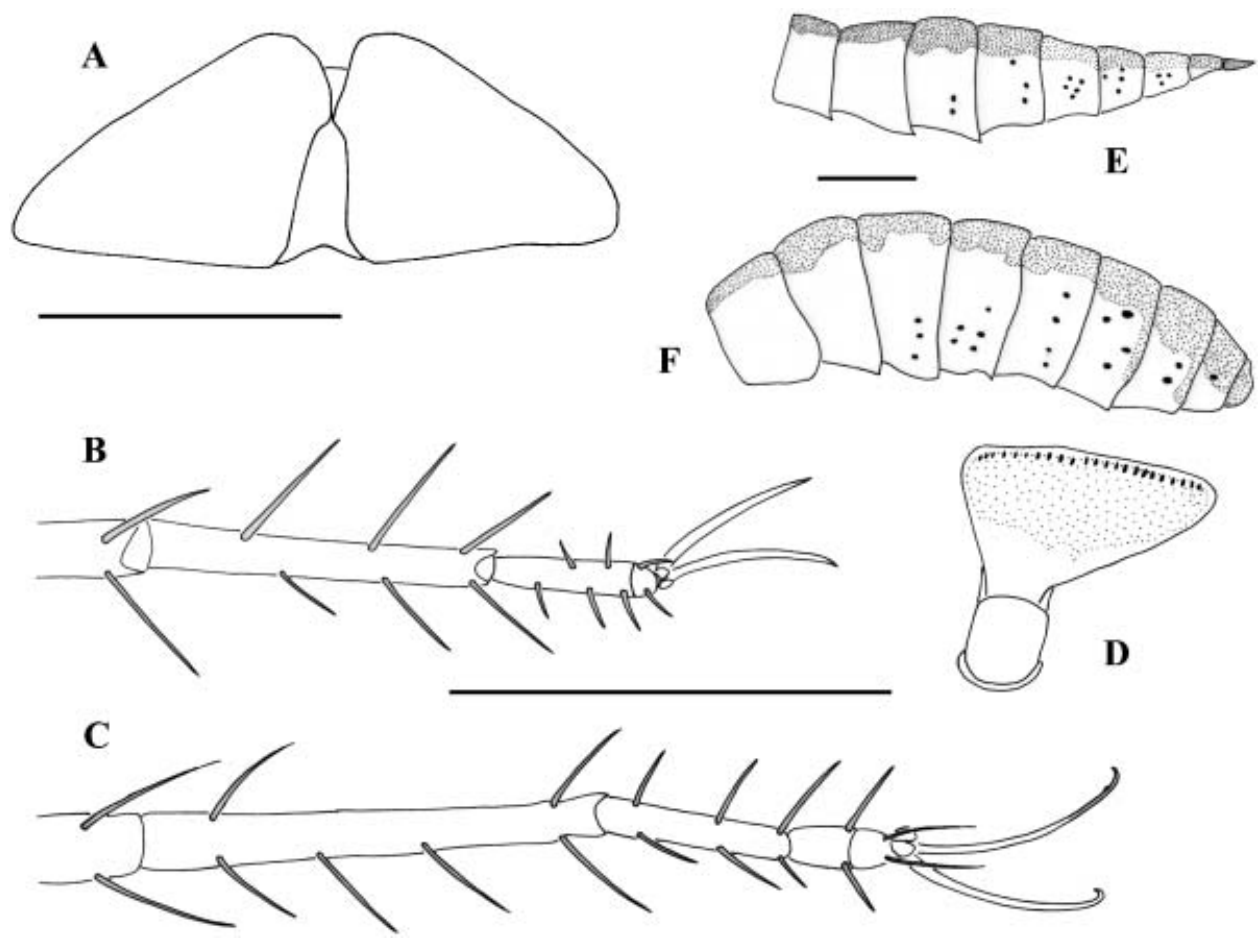

FIG. 4. Mummucia coaraciandu n. sp. (A) Genital operculum of female; (B) male leg III; (C) male leg IV; (D) right malleolus $\mathrm{V}$ of male holotype; (E) left pleurites of male; (F) left pleurites of female. Scale bars: $1 \mathrm{~mm}$. 
and legs brown, ventral and lateral face white. Malleoli pale brown with large brown spots on the enlarged portion (figure 4D).

Opisthosoma: lateral borders of the tergites white, with a wide dark brown stripe on the central half, which is darker near the posterior border of the tergites. White area of the tergites covered by brown bifid setae with brown sockets. Pleurites white on the ventral portion, dorsal portion dark brown with distal margin white. Pale brown translucent bifid bristles in the white portion have sockets shaped into dark brown spots (figure 4E). Sternites white, lateral borders brownish, last two sternites almost totally brownish. Anal segment almost totally brown. First to fourth postspiracular sternites with brown spots which include the sockets of some bifid bristles. All covering bristles and bifid bristles are translucent yellowish.

Morphology and chaetotaxy. Prosoma: propeltidium with some scattered bifid setae, wider than long (table 1) and separated from lateral lobes by dorsal grooves. Ocular tubercle prominent with bifid setae anteriad, followed by four setae (lateral half of median) and two rows of setae. Distance between two eyes about 1.5 times eye diameter. Peltidium narrow, with a transverse row of bifid setae. Parapeltidium smooth. Mesopeltidium semicircle-shaped, 2.5 times wider than long, with one row of normal setae on posterior margin. Metapeltidium 1.6 times wider than long.

Chelicerae (figure 3A, B): stridulatory apparatus on mesal face with six parallel grooves. Ectal face with several short bristles and setae, both bifid and acuminate. Movable finger with one anterior, one intermediate, and one principal tooth, graded in size from distal to proximal I, III and II. Fixed finger dentition: three anterior teeth (the first one may be vestigial), one intermediate and one principal tooth, graded in size from distal to proximal II, IV, I, V, III. Three mesal fondal teeth, graded in size from distal to proximal I, II, III, the first distal separated from the others by a diastema. Five ectal fondal teeth graded in size from distal to proximal I, II, V, III, IV. Fixed finger bears, centrally on its dorsal face, one very long seta (about the length of femur III) with a prominent socket.

Flagellum (figure 3B): flagellum is a thin translucent drop-shaped vesicle, laterally flattened as in other mummuciids. It bears a longitudinal ectal opening on

Table 1. Morphometric characters of Mummucia coaraciandu n. sp.

\begin{tabular}{|c|c|c|c|c|}
\hline \multirow[b]{2}{*}{ Character } & \multirow[b]{2}{*}{$\begin{array}{l}\text { Holotype, male } \\
\text { (MZSP-20948) }\end{array}$} & \multirow[b]{2}{*}{$\begin{array}{l}\text { Paratype, female } \\
\text { (MZSP-20409) }\end{array}$} & \multicolumn{2}{|c|}{ Range } \\
\hline & & & $\begin{array}{c}\text { Males } \\
(N=18)\end{array}$ & $\begin{array}{c}\text { Females } \\
(N=5)\end{array}$ \\
\hline Total length & 8.9 & 10.9 & $7.1-8.9$ & $9.1-10.9$ \\
\hline Cheliceral length & 2.4 & 3.1 & $2.0-2.4$ & $2.5-3.1$ \\
\hline Cheliceral width & 0.9 & 1.1 & $0.7-1.1$ & $0.8-1.1$ \\
\hline Propeltidium length & 1.5 & 1.7 & $1.3-1.7$ & $1.4-1.7$ \\
\hline Propeltidium width & 1.9 & 2.4 & $1.5-2.4$ & $2.1-2.4$ \\
\hline Propeltidium length/width ratio & 0.79 & 0.71 & $0.71-0.87$ & $0.67-0.71$ \\
\hline Pedipalp length & 6.3 & 6.6 & $4.8-6.6$ & $5.7-6.6$ \\
\hline Leg I length & 4.4 & 4.9 & $4.3-4.9$ & $4.4-4.9$ \\
\hline Leg IV length & 8.7 & 9.2 & $8.5-9.2$ & $9.2-9.3$ \\
\hline
\end{tabular}

Measurements are in millimetres (except length/width ratio) and were recorded as described in Muma (1951). 
the face adjacent to the chelicera. The attachment base of the flagellum is a sclerotized ring placed posteriorly on its ectal face.

Pedipalp: tarsi immovable, without spines, densely covered by differentially sized bifid bristles, with some very long setae in tibiae and patellae (about 1.4 times pedipalpal tibial length).

Legs: covered by several differentially sized bifid bristles and some bifid setae. Some very long setae on the dorsal surface (about 1.5 times the basitarsus IV length). Leg I: thin, without claws and spines. Legs II and III: tibiae with 1.1 ventral bifid spines and a distal pair of ventral spines; basitarsus with three retrolateral spines and 1.1.2 ventral spines; telotarsi two-segmented with 1.2.2/2.2 ventral spines (figure 4B). Leg IV: tibia with an anterior row of 1.1 .1 ventral bifid spines and a distal pair of ventral spines; basitarsus with 1.1.1.2 ventral spines; telotarsi three-segmented, with 2.2.2/2/2.2 ventral spines (figure 4C). Malleoli as in figure 4D.

Opisthosoma: tergites wider than long, with rounded borders, covered by bifid setae and bifid bristles. Genital operculum with central longitudinal opening. Sternites wider than long, densely covered by bifid bristles. Two post-spiracular sternites with several long and acuminate bristles, 1.4 times longer than other sternite bristles. The measurements are shown in table 1 .

\section{Description of female (figures 2B, 3C, D, 4A, F)}

Similar to male, except for the following features.

Morphology and chaetotaxy. Prosoma: propeltidium wider than long with numerous bifid setae and small bifid bristles. Eyes separated by twice their diameter.

Chelicerae (figure 3C, D): stridulatory apparatus similar to male. Movable finger with one anterior, one intermediate and one principal tooth graded in size from distal to proximal III, I, II. Fixed finger with three anterior, one intermediate and one principal tooth graded in size from distal to proximal: III, V, II, IV, I and six ectal fondal teeth, graded in size: I, III, IV, II, V, VI.

Leg $I V$ : tibia with an anterior row of 1.1 .1 ventral bifid spines and a distal pair of ventral spines; basitarsus with 1.1.1.2 ventral spines and a proximal anterior row of 1.1 ventral bifid spines.

Opisthosoma: sternites densely and uniformly covered by bifid bristles, without conspicuous sockets. Genital operculum (figure 4A) prominent, round-bordered, with central longitudinal opening. Pleurites as in figure $4 \mathrm{~F}$. The measurements are shown in table 1 .

\section{Phenology}

Six hundred and forty-nine individuals of Mummucia coaraciandu were trapped in the three Cerrado physiognomies. Males accounted for 549 of all trapped individuals, whereas females and juveniles accounted for 87 and 13 individuals, respectively. There was a clear seasonal pattern in the number of individuals trapped, with most being captured in June and July (figure 5B). This number decreased to zero in September and then increased again, reaching a minor peak between December 2000 and February 2001. In March 2001, the number of individuals trapped decreased to zero again and then started to increase in April (figure 5B). The number of individuals correlated negatively with the mean monthly 
temperature $\left(F=10.01 ; R^{2}=0.50 ; P=0.009\right)$, but was not correlated with the mean monthly precipitation $\left(F=2.35 ; R^{2}=0.19 ; P=0.15\right)$.

The mean sex ratio was male-biased $(7: 1)$ throughout the study period (figure 6A). Juveniles were trapped only from May to July, and in November and February (figure 6A). Most females trapped during the warm-wet season had reduced ovaries, whereas most of those trapped during the cold-dry season had partially or fully developed ovaries (figure 6B). The number of males trapped was positively correlated with the number of reproductive females $\left(r_{\mathrm{s}}=0.60\right.$; $P=0.04)$.

Habitat use and activity pattern

Mummucia coaraciandu preferentially used the campo sujo where the largest number of individuals were trapped $(N=561)$. In the campo cerrado and gallery forest, 35 and 53 individuals were trapped, respectively $\left(\chi^{2}=824.4 ; \mathrm{df}=2\right.$;
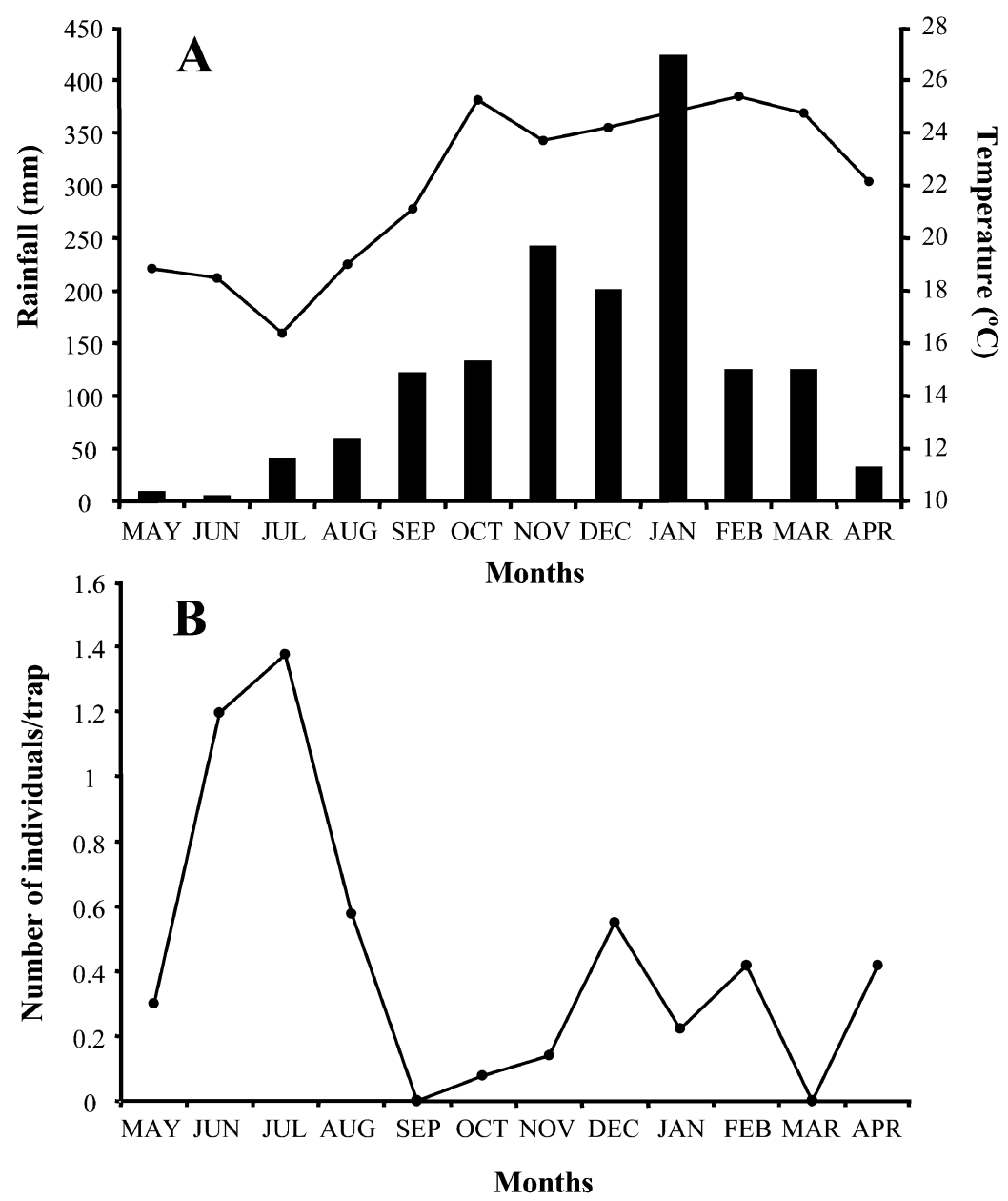

FIG. 5. (A) Mean monthly temperature (line) and precipitation (bars) at Itirapina Ecological Station, during the study period (April 2000 to May 2001); (B) total number of individuals of the solifuge Mummucia coaraciand $u$ n. sp. trapped per month. 

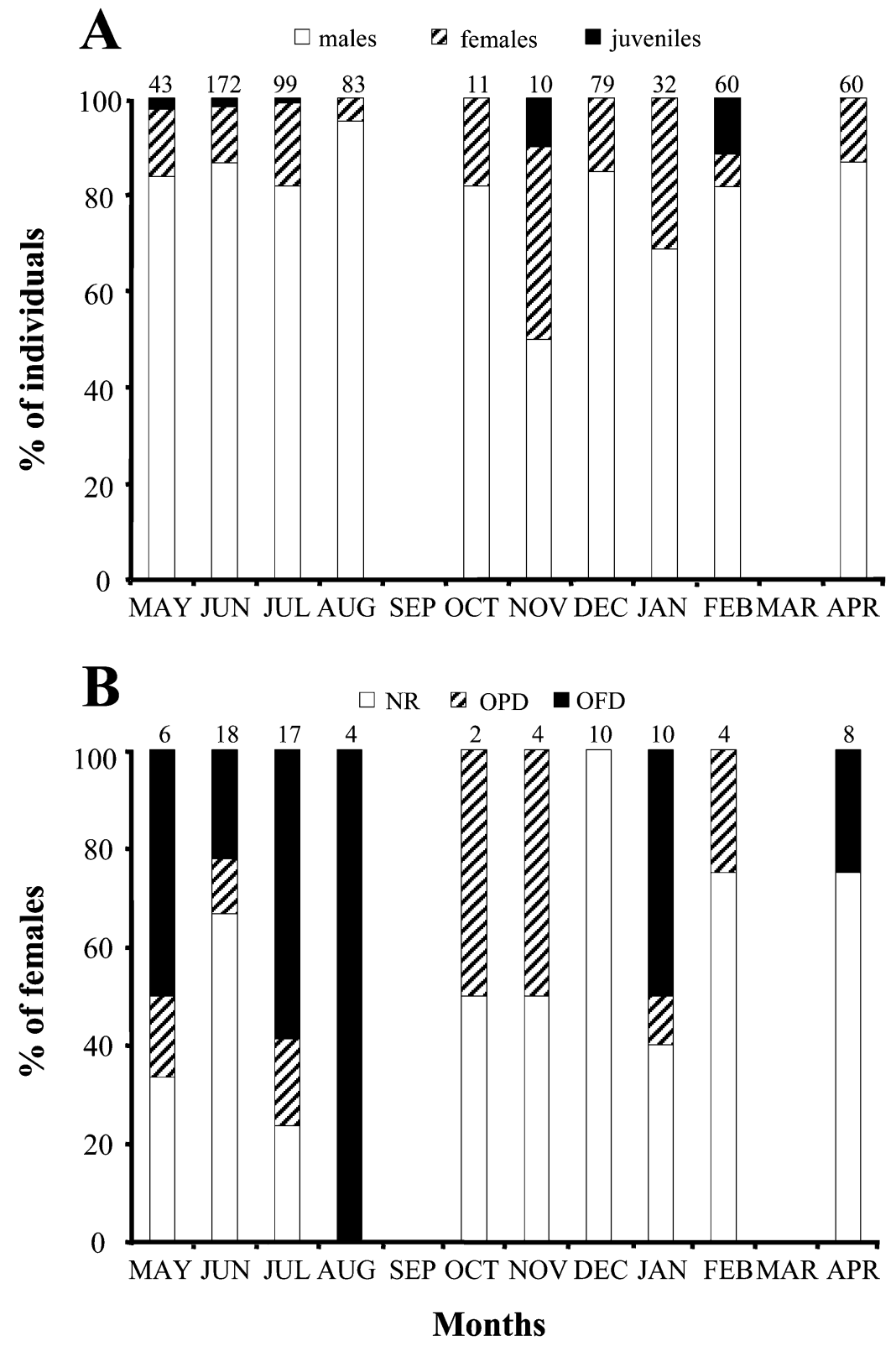

FIg. 6. (A) Number of males, females and juveniles (all stages pooled) of the solifuge Mummucia coaraciandu n. sp. trapped per month at Itirapina Ecological Station. The numbers above each column correspond to the total number of individuals collected. (B) Reproductive condition of females of M. coaraciandu n. sp. throughout the year. The numbers above each column correspond to the total number of females examined. NR, non-reproductive; OPD, ovary partially developed; OFD, ovary fully developed (see text for category definitions).

$P<0.0001)$. Individuals of $M$. coaraciand $u$ were more active during the day (06:00-18:00 h; $N=120$ individuals) than at night (18:00-06:00 h; $N=3$ individuals). 


\section{Fire effect}

More individuals of $M$. coaraciandu were trapped in burned areas of campo sujo when compared with unburned areas of the same physiognomy 1 month after the fire $\left(\chi^{2}=13.92 ; \mathrm{df}=1 ; P=0.0002\right)$ (figure 7). This difference between the two areas was not observed 1 month before $\left(\chi^{2}=0.39 ; \mathrm{df}=1 ; P=0.58\right)$ and $3-4$ months after $\left(\chi^{2}=1.0 ; \mathrm{df}=1 ; P=0.317\right)$ the fire (figure 7$)$.

\section{Discussion}

\section{Taxonomical comments}

There is no consensus about the number and systematic position of the genera within the family Mummuciidae. According to Maury (1998) and Xavier and Rocha (2001), there are no good characters to distinguish the genera of Mummuciidae, so that the most conservative decision is to consider the new species described herein as belonging to the typical genus Mummucia, until more precise information on the taxonomy and phylogeny of the group become available.

Two main features may be used to distinguish all the 19 species of Mummuciidae (M. coaraciandu included): cheliceral dentition and flagellum morphology. The presence of three anterior teeth in the fixed finger is diagnostic for $M$. coaraciandu, since a similar feature is not found in other Brazilian mumuciids. The other mummuciids with three anterior teeth are: Uspallata pulchra Mello-Leitão, 1938 and Mummucia mendoza Roewer, 1934 from Argentina; Mummucina colinalis Kraus, 1966 and Mummucia variegata Gervais, 1849 from Chile; and Mummucina titschacki Roewer, 1934 from Ecuador. The remaining 13 species bear only two anterior teeth. In addition, cheliceral dentition of $M$. coaraciandu, if considered as a whole, is unique among mummuciids.

The shape of the flagellum is another character currently used for definition of Neotropical families, and in the Mummuciidae the flagellum is vesicular (Maury, 1984). However, flagellum morphology is very similar in all mummuciid species,

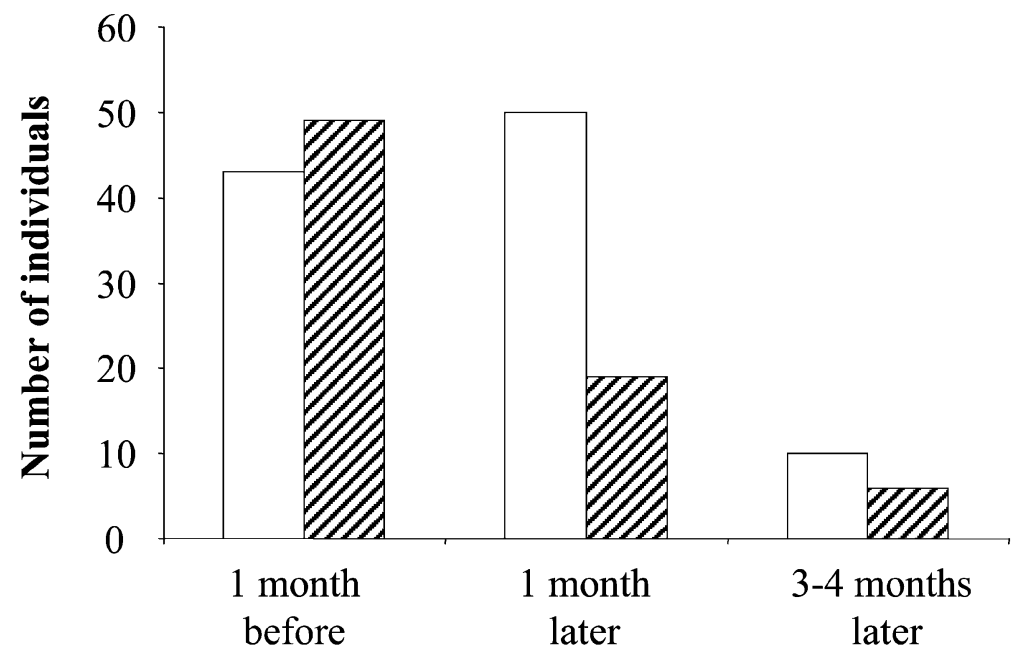

FIG. 7. Number of individuals of the solifuge Mummucia coaraciandu n. sp. trapped in burned (white bars) and unburned (hatched bars) areas of campo sujo at the Itirapina Ecological Station at three different moments relative to the fire event. 
except for the presence of a longitudinal ectal opening, which was reported only for M. coaraciandu, Metacleobis fulvipes (redescription in Rocha and Cancello, 2002b) and Mummucia mauryi Rocha, 2001.

Finally, the dark brown spots in opisthosomal pleurites of $M$. coaraciandu (figure 3E, F) are arranged in a pattern distinct from those found in Metacleobis fulvipes and Mummucia mauryi. Even though these patterns are somewhat polymorphic, they are notably distinct in these three species. Unfortunately, the coloration of the pleurites was not described for the other mummucid species, which hampers the use of this character as a source of taxonomical information.

\section{Phenology}

Life history patterns result from both evolutionary constraints and proximate responses of the organisms to specific environmental conditions (Stearns, 1992). Several biotic and abiotic factors, such as temperature, rainfall and prey abundance, may account for the phenology of solifuges (Cloudsley-Thompson, 1977; Punzo, 1998). The surface activity of Mummucia coaraciandu was negatively correlated with the monthly temperature, and showed a clear peak during the colddry season (June to August), with a second small peak in the middle of the warmwet season (December to January). The first peak coincided with the greatest number of reproductive females and probably corresponded to the breeding season of $M$. coaraciandu. Laying eggs at the end of the cold-dry season may represent a synchronization of the maternal investment in offspring with ideal conditions for juvenile hatching and growth during the warm-wet season (October to March), when arthropod prey is more abundant in the Cerrado (Pinheiro et al., 2002). The same pattern occurs with Sudan and North American solifuge species in which reproduction is adjusted to the climatic conditions so that the young hatch during the period of the annual desert rains, when there is great food availability (see Cloudsley-Thompson, 1977). The second peak may represent a second reproductive event of females that laid eggs earlier in the cold-dry season and had time for their eggs to mature so that they could produce another batch. However, this peak should be interpreted with caution since the number of females trapped in October, November and February was very small.

Males of $M$. coaraciand $u$ were more commonly caught throughout the year and this pattern was similar to previous studies with solifuges (see Punzo, 1998). This bias is generally considered as an artefact of the collecting method rather than a natural phenomenon (Punzo, 1998). Males of several arthropod groups exhibit greater activity on the ground and are thus more likely to be caught in pitfall traps (see discussion in Polis et al., 1998). Larger displacements by males of several arthropod species are considered as a behavioural strategy to increase encounters with females and, hence, their reproductive success (Polis et al., 1998). If this explanation is also true for solifuges, increased surface activity should occur mainly during the reproductive periods, when females are receptive to copulation. Indeed, our results showed that the number of males trapped was positively correlated with the number of reproductive females. Because of increased movement during the breeding season, males of $M$. coaraciandu are probably more exposed to predation during this period. Therefore, this species should be a good model organism for investigating the ecological costs of reproduction and how differential predation may affect the operational sex ratio in natural populations. 
Only a few juveniles were trapped and their surface activity showed no clear seasonal pattern. Previous studies have suggested that pitfall traps are not an appropriate method for sampling juvenile solifuges since they rarely move away from the burrow entrance and generally show a clumped distribution (Punzo, 1998). Indeed, most studies on the phenology of solifuges have dealt only with adults, which are more likely to fall into the traps (see Punzo, 1998). Information on the occurrence of the different nymph stages throughout the year (obtained with other capture methods) is crucial for a better understanding of the phenology of $M$. coaraciandu.

\section{Habitat use and activity pattern}

The use of burrows for resting, digestion, ecdysis, hibernation and oviposition is widespread among solifuges (Muma, 1966). It seems reasonable to suppose that the type of substratum influences this behaviour, and this could explain the different occurrences of $M$. coaraciandu in the Cerrado physiognomies. The soil in gallery forest is usually muddy and subject to seasonal flooding during the warm-wet season. Shelters constructed in this habitat may be risky for the newly hatched nymphs, and especially for eggs. Campo sujo soil is sandier than that of campo cerrado, in which there is more silt and clay (R. J. Sawaya, unpublished data). Since solifuges lack special morphological features for digging (Muma, 1966), sandy soil, such as that in campo sujo, could reduce the energy costs of burrowing (Gore and Cushing, 1980; Punzo, 1998). Besides, campo sujo is the predominant physiognomy at the Itirapina Ecological Station, and probably harbours a more diversified and specialized fauna, as seen for other animal groups, such as snakes (R. J. Sawaya, unpublished data).

Food supply cannot explain the habitat use by $M$. coaraciandu since there was no significant difference between campo sujo and campo cerrado in the abundance of ground arthropods that could be used as prey by these solifuges (Machado et al., in preparation). Other factors that could account for the remarkable abundance of $M$. coaraciandu in campo sujo include the density of predators and competitors, the availability of retreats and even the type of vegetation. There is no clear pattern of habitat use among solifuges occurring in arid and semi-arid regions. Some species show a preference for open areas, whereas others are restricted to areas with plant cover (Griffin, 1990; Dean and Griffin, 1993; Punzo, 1998). The type of vegetation seems to be important, and some studies have shown that the abundance of solifuges in areas with mixed plant associations is higher than in single plant areas (Muma, 1980; Punzo, 1998).

With few exceptions, larger solifuges are strictly nocturnal while the smaller species are active during daytime (Cloudsley-Thompson, 1977, but see Wharton, 1987). Based on this general pattern, the small species of the family Mummuciidae should have diurnal habits (Maury, 1984; Xavier and Rocha, 2001). Indeed, traps examined early in the morning contained few solifuges, indicating that the surface activity of $M$. coaraciandu was mainly diurnal. Similar results were reported for M. mauryi in the Brazilian Caatinga (Xavier and Rocha, 2001).

Diurnal solifuges are exposed to visually orientated predators such as birds and lizards, and one would expect to find primary defensive mechanisms (sensu Edmunds, 1974) to prevent predation. In agreement with this, males and females of $M$. coaraciandu had a colour pattern that can be considered cryptic against a 
background of sand (see figure 2A, B). Habitat selection probably also affords protection because in areas covered by vegetation individuals decrease their chance of being detected by predators (Punzo, 1998). The congeneric M. mauryi avoids sun-exposed areas and prefers areas covered with the cactus Opuntia inamoena, where the access of vertebrate predators is reduced (Xavier and Rocha, 2001).

\section{Effect of fire}

There was a clear effect of fire on the population of $M$. coaraciandu. Immediately after burning, the capture rate increased more than two times when compared with unburned areas of campo sujo. This difference was not observed 3-4 months after burning, when the number of individuals trapped was similar between the two areas and the vegetation had apparently recuperated. Fire destroys grass vegetation and reduces the abundance of arthropod prey. This obliges the predators to search a larger area to find food. As a consequence, they increase their chance of being trapped in pitfalls.

The effect of fire on arachnids has been evaluated for scorpion populations in a savanna area of Australia (Smith, 1990). Although the latter study was done 1 year after burning, the results indicated that there was no decrease in the populations of burrowing species after fire, whereas non-burrowing species were negatively affected and were less likely to persist through frequent fires. Field and laboratory observations indicate that $M$. coaraciandu builds small burrows (G. Machado, personal observation). However, our data did not allow us to determine whether individuals of $M$. coaraciand $u$ can withstand perturbation as strong as fire. If they cannot, then the increased number of trapped individuals implies re-colonization of this area by individuals from neighbouring unburned areas.

\section{Acknowledgements}

The authors thank L. A. Anjos, C. A. Brasileiro, V. C. Fox, M. C. Kiefer, R. J. Sawaya, F. Spina and several other friends for help in the fieldwork. R. J. Sawaya took the photographs of the live animals. A. J. Santos, A. S. Melo, R. J. Sawaya, F. Punzo and an anonymous reviewer provided helpful comments on an early draft of the manuscript. This is publication No.13 of the project 'Ecology of the Cerrados of Itirapina'. This work was supported by the Fundação de Amparo à Pesquisa do Estado de São Paulo and Conselho Nacional de Desenvolvimento Científico e Tecnológico.

\section{References}

Cloudsley-Thompson, J. L., 1977, Adaptational biology of Solifugae (Solpugida), Bulletin of the British Arachnological Society, 4, 61-71.

Dean, W. R. J. and GRIFFIn, E., 1993, Seasonal activity patterns and habitats in Solifugae (Arachnida) in southern Karoo, South African Journal of Zoology, 28, 91-94.

Edmunds, M., 1974, Defence in Animals: A Survey of Anti-Predator Defences (Harlow: Longman).

Gore, J. A. and Cushing, B. S., 1980, Observations on temporary foraging areas and burrows of the sun spider, Ammotrechula penninsulana (Banks) (Arachnida: Solpugida), Southwestern Naturalist, 25, 95-102.

GRIfFIN, E., 1990, Seasonal activity, habitat selection and species richness of Solifugae (Arachnida) on the gravel plains of the Central Namib Desert, Transvaal Museum Monograph, 7, 80-82. 
MAURY, E. A., 1984, Las familias de solífugos americanos y su distribuición geográfica (Arachnida, Solifugae), Physis C, 42, 73-80.

Maury, E. A., 1998, Solifugae, in J. J. Morrone and S. Coscarón (eds) Biodiversidad de Artrópodos Argentinos (La Plata: Ediciones SUR), pp. 560-568.

Mello-Leitão, C., 1924, A new South-American solpugid, Revista Chilena de Historia Natural, 28, 140-143.

Miranda, H. S., Bustamante, M. M. C. and Miranda, A. C., 2002, The fire factor, in P. S. Oliveira and R. J. Marquis (eds) Ecology and Natural History of a Neotropical Savanna (New York: Columbia University Press), pp. 51-68.

Muma, M. H., 1951, The arachnid order Solpugida in the United States, Bulletin of the American Museum of Natural History, 97, 35-141.

Muma, M. H., 1966, Burrowing habits of North American Solpugida (Arachnida), Psyche, 73, 251-260.

Muma, M. H., 1980, Comparison of three methods for estimating solpugid (Arachnida) populations, Journal of Arachnology, 8, 267-270.

NEw, T. R., 1999, By-catch, ethics, and pitfall traps, Journal of Insect Conservation, 3, 1-3.

Oliveira-Filho, A. T. and RATTER, J. A., 2002, Vegetation physiognomies and woody flora of the Cerrado biome, in P. S. Oliveira and R. J. Marquis (eds) Ecology and Natural History of a Neotropical Savanna (New York: Columbia University Press), pp. 91-120.

Pinheiro, F., Diniz, I. R., Coelho, D. and Bandeira, M. P. S., 2002, Seasonal pattern of insect abundance in the Brazilian Cerrado, Austral Ecology, 27, 132-136.

Polis, G. A., Barnes, J. D., Seely, M. K., Henschel, J. R. and Enders, M. M., 1998, Predation as a major cost of reproduction in Namib desert tenebrionid beetles, Ecology, 79, 2560-2566.

Punzo, F., 1998, The Biology of Camel Spiders (Arachnida, Solifugae) (Dordrecht: Kluwer Academic Publishers).

Rocha, L. S. and CANCello, E. M., 2002a, Arachnida-Solifugae, Fauna da Amazônia Brasileira, 22, 1-3.

Rocha, L. S. and Cancello, E. M., 2002b, Redescription of Metacleobis fulvipes Roewer from Brazil (Solifugae, Mummuciidae), Journal of Arachnology, 30, 104-109.

Roewer, C. F., 1934, Solifugae, Palpigradi, in H. G. Bronns (ed.) Klassen und Ordungen des Tierreichs (Leipzig: Akademische Verlagsgesellschaft M. B. H.), Vol. 5, Div. 4, Book 4, pp. 461-608.

Roewer, C. F., 1954, Einige neue Opiliones Laniatores und Solifugae, Abhandlungen Naturwiessenschaftlichen Verein Zu Bremen, 33, 377-384.

SMITH, G. T., 1990, Responses by scorpions to fire-initiated succession in arid Australian spinifex grasslands, Journal of Arachnology, 18, 241-244.

SoKal, R. S. and Rohlf, F. J., 1995, Biometry: The Principles and Practice of Statistics in Biological Research (San Francisco: W. H. Freeman and Co.).

Stearns, S. C., 1992, The Evolution of Life Histories (Oxford: Oxford University Press).

XAVIER, E. and Rocha, L. S., 2001, Autoecology and description of Mummucia mauryi (Solifuage, Mummuciidae), a new solifuge from Brazilian semi-arid Caatinga, Journal of Arachnology, 29, 127-134.

Wharton, R. A., 1987, Biology of the diurnal Metasolpuga picta (Kraepelin) (Solifugae, Solpugidae) compared with that of nocturnal species, Journal of Arachnology, 14, 363-383. 